\title{
A Systematic Bibliometric Review of the Strategic Entrepreneurship
}

\section{Domain}

\begin{abstract}
Purpose - The strategic entrepreneurship literature exists at the intersection of the strategy and entrepreneurship literatures and has grown rapidly over the past two decades. This article documents the proliferation of research papers and identifies the major thematic clusters of topics and other summary information for the strategic entrepreneurship research domain.
\end{abstract}

Design/methodology/approach - This is a systematic bibliometric review of 586 articles published over the period 2009-2019 in 143 journals. Our inductive quantitative assessment of these articles employs meta-data driven techniques that prioritize reproducibility and rigor in the process of literature analysis.

Findings - This article identifies six main themes in the strategic literature, namely Sustainable Competitive Advantage; Knowledge Management; Ecosystems; Strategy; Entrepreneurialism; and Organization \& Management. It also reports data on a variety of issues including research techniques, country of data, co-author count and trends, and differences between journals based on their journal impact factors and calls for more research in key areas.

\section{Originality -}

An innovative original analytical tool was developed to facilitate the analysis of research articles in this growing field. This online tool allows multiple tags to be attached to each article by multiple authors working simultaneously to identify keywords and other aspects that were subsequently utilized to identify six main thematic areas within the strategic entrepreneurship literature. This paper highlights emerging research trends and identifies gaps in the literature that provide opportunities for further research in this field.

Paper type - Literature review 


\section{Introduction}

In the past two decades "strategic entrepreneurship" (SE) has emerged as a major field of entrepreneurship research at the intersection between strategy and entrepreneurship. In contrast with strategic management, which is seen as effective and efficient resource management of the firm, SE integrates the entrepreneurial perspective (i.e., opportunity-seeking behavior) with the strategy perspective (i.e., advantage-seeking behavior) (Davidsson 2014; $\underline{\text { Hitt et al., 2001; Ireland }}$ and Webb 2009; Ketchen et al., 2007; Simsek et al., 2017; Sirén et al., 2012). Where strategic management's focus is primarily on operational and financial efficiencies, strategic entrepreneurship's focus is on the continuous practice of entrepreneurial rejuvenation of the firm, by the exploration for and the exploitation of new products and services (Mathias et al., 2018; Parida et al., 2016; Raisch and Birkinshaw, 2008). Although strategic entrepreneurial behavior can be undertaken by individuals, firms, and nations, the focus of the emerging SE field is primarily at the firm level and is therefore largely concerned with corporate entrepreneurship.

Like the wider entrepreneurship literature, SE benefits from contributions from a wide range of research fields, including management, economics, psychology, and sociology, and often spans multiple disciplines. As a result, a substantial diversity of topic areas is considered by authors, editors and reviewers as belonging in the SE domain, highlighting the need for a census of prior research, an overview of the major streams of research, and an examination of how the research domain is progressing. Thus, the purpose of this study is to conduct a systematic bibliometric analysis of research papers from the SE domain, and by so doing, inductively reveal the main thematic areas and sub-topics that constitute the domain. This inductive examination is important because it: (1) documents the growth and proliferation of the SE domain globally and across different journals; (2) examines the conceptual vs. empirical, qualitative vs. quantitative, 
country of data, sample size, and other research practices and analytical techniques employed by researchers; (3) provides an overview of the keywords and the aggregation of these into main thematic areas for the benefit of researchers in SE and in adjacent fields where SE may be applied, such as the hospitality, education and sports-management literatures; and finally, (4) suggests future research issues and topics that could contribute to the SE literature.

In the following section, we outline our sample selection and systematic bibliometric analysis methods. Next, we provide statistical analysis of the characteristics of the papers in terms of their authors, journals, research contexts, data sources, and so on. In the third section we characterize articles by keywords and other content indicators and identify clusters that have emerged in the SE field over the preceding decade. Finally, we discuss our findings and note the opportunities for further research in the SE domain.

\section{Survey Research Method}

Prioritizing transparent and reproducible processes (Tranfield et al., 2003; de Vasconcelos Gomes, et al., 2018), we undertook a quantitative "bottom-up" approach to identify the major themes and sub-topics, rather than a qualitative "top-down approach" that starts with highly-cited papers and predetermined research themes (e.g. Linan and Foyolle, 2015). Using a web-based meta-tagging technique to systematically analyze our sample, each article was tagged with keywords and other distinguishing features using a web interface to an online database. Finally, bibliometric tools were employed to inductively determine the main themes and trends in the literature.

\section{Sample Selection}

Our intention was to gather as many articles as possible that fall within the SE domain based on a rigorous, reproducible procedure. This review follows the PRISMA (Preferred Reporting Items for Systematic reviews and Meta-Analyses) procedure, following a 27-point checklist on good practice 
for systematic reviews and a four-step process flow for identifying relevant articles - i.e., from identification, to screening, to eligibility assessment, to inclusion (Liberati et al., 2009). Using the PRISMA approach, the analysis built on previous literature reviews with a procedural approach informed by prior research in the methodological and entrepreneurship literature (Pittaway et al., 2004; Raisch and Birkinshaw, 2008; Tranfield et al., 2003).

To fully represent the literature and to understand the breadth of the domain, a series of dummy searches was made using the Pro-Quest database. We settled on the search terms "strategic" (plus) "entrepreneurship" which returned a total of 1,031 articles. One hundred and eighty non-English language articles and duplications were removed, leaving 851 articles from 390 journals. To reduce this large number of articles to a more manageable total, the journal impact factor (JIF) for each journal was sourced from Academic Accelerator ${ }^{1}$, and journals without a JIF, or with a JIF less than 1.000, were screened out, leaving 482 articles from 174 journals ${ }^{2}$. We included a further 180 articles that were published in the Strategic Entrepreneurship Journal (SEJ) during the same period. These 662 articles were read by at least two of the reviewers to ensure that each article was indeed pertinent to SE (following the approach adopted by Liñán and Fayolle, 2015), a process which resulted in the elimination of 76 articles (from 31 journals). Rejected articles often contained book reviews or were focused on a subfield of strategy or entrepreneurship, rather than the intersection of the two domains, or had used the search terms casually. Figure 1 shows the workflow adopted.

[insert Figure 1 near here]

\footnotetext{
${ }^{1}$ See www.academic-accelerator.com

${ }^{2}$ To better identify trends within the literature relating to journal rating, the authors created four tiers of journals based on JIF ratings as follows: Tier 1 journals JIF 4.000 and above; Tier 2, 2.950 - 3.999; Tier 3: 1.500-2.949; Tier 4: 1.000-1.499.
} 


\section{Bibliometric Analysis Procedures}

Following the approach outlined by Tranfield et al.,(2003), the reviewers first created tags for a variety of words and phrases deemed to be of interest for this study, adding these to an initial set of keywords based on a word frequency search of the abstracts. Adopting a multi-layered tagging process, other characteristics were ascribed to each article. An iterative process of reviewing the articles was employed to ensure that the reviewers responded to the emergence of appropriate tags not foreseen pre-analysis. Each article received multiple tags and was reviewed by at least two reviewers with another reviewer reconciling differences. Every effort was made to utilize the keywords nominated by authors, but in many cases their keywords were overly generic (for example, "entrepreneurship") or were simply not indicated. Additional keyword allocation was heavily based on the wording used in the abstract, and where doubts or inter-reviewer differences arose, the entire article was perused more carefully, and appropriate keywords were assigned. After an iterative process of checking and rechecking articles, 148 keywords were defined, and these are shown in Table 1 later in the paper.

\section{Descriptive Statistics}

The yearly total of SE articles has grown by $50 \%$ during the review period. This compares with Busenitz et al.'s (2003) finding that the rate of publication of the wider entrepreneurship domain had increased by $62 \%$ over the period $1985-1999$.

\section{Authors}

There were 1,238 unique authors, writing in a total of 143 journals over the period 2009-2019. Sole-authored articles account for $14.7 \%$ of all articles in our sample, with $32.7 \%$ written by two authors, $31.8 \%$ by three authors; and the remaining $20.8 \%$ by four or more authors. Examination of the author-count trend reveals that although the proportion of single-author articles remains 
relatively stable, the share of dual-author articles is in decline - they accounted for $39 \%$ of articles in 2009 but only $22 \%$ by 2019 . Thus, there has been a gradual decline in the number of dual authors, and there is a marked emergence trend of four, five, and more co-authors per article. There are differences in this trend, depending on the JIF of the journal in question, and it is more evident in articles published in lower-JIF ranked journals from 2012 onwards where there has been a gradual decline in the number of single authors and a shift to multi-author articles, and the emergence of four or more co-authors per article is marked.

\section{Journals}

The search revealed a gradual increase in the number of journals in our sample each year, from 19 in 2009 to 35 in 2019. This exemplifies the steady spread of the SE domain. Of the 143 journals over the period 2001-2019, only 17 published articles in five or more of the 11 years, and 82 journals published only one of the included articles over the 11 years. This reveals in absolute terms that the domain is indeed spreading, with articles appearing in a greater breadth of journals. A similar pattern can be seen if we examine the field of research of the journals. Over $70 \%$ of the journals in the sample are classified as business and management journals, but a closer examination of the trend reveals a broadening in the journals that are publishing articles on SE. Whereas in $2009,100 \%$ of articles were published in business and management journals, by $2019,15 \%$ of articles appeared in other applied-management journals.

\section{Article Design}

[Table 1 near here]

Sixty-seven per cent of the 586 articles published between 2009 and 2019 were empirical in nature; $23 \%$ were conceptual, $7 \%$ were literature reviews (40 articles), and the remaining $3 \%$ were methodological. Busenitz et al., (2003) suggest that once the boundaries of a discipline become clearer, theoretical discussions give way to greater empirical work. In the case of SE, the number 
of conceptual articles grew over the survey period and accounted for $27.3 \%$ of all articles published in 2019, suggesting that the boundaries of the SE domain remain unclear.

\section{Research Context}

Seventy countries featured in the $341(58 \%)$ of articles where a specific country was mentioned by authors. The USA was the primary source of data in 98 (29\%) of these studies. Other major countrybased centers of research were China (10\%), the UK (8\%) and Germany $(6 \%)$. Studies based on UK and European data continue to comprise the major share of articles (approximately $40 \%$ over the period of analysis). Our findings reflect the continuing rise of China over the decade, and the trends suggest that although articles using UK and European data continue to grow (and maintain a constant share of articles published), North American research is in relative decline, counterbalanced by a relative increase in the research from Asian countries. Of notable absence is Japan, for which our search returned only three publications utilizing Japanese data.

A total of 278 articles $(47.4 \%$ of the total) referenced a specific industry or group of industries. Single-industry studies were the focus of $164(59 \%)$ of these articles, while multiple sector unspecified "high-tech" sectors are also favored by researchers (12.5\%). The education sector remains a rich source of data with 26 articles (9\%) overall using data (usually collected from students or alumni) from this sector, more than any other specified single sector. In $2019,11 \%$ percent of articles where an industrial sector is mentioned featured research on the education sector, reflecting a steady increase on previous years.

\section{Data Sources}

Research focusing on firm growth typically conducted comparative studies on entrepreneurial differences between countries in a particular sector (e.g., Autio and Acs, 2010) and typically utilized data from secondary data sources. Sample sizes from these sources were usually very large (for example, the 2019 World Bank database, and GEM data). Ninety-one articles (23\% of articles 
where data source was tagged) used secondary data, while 297 articles (77\%) used primary data collected by the authors. There is a noticeable difference in the source of data used when viewed by journal tier - in Tier 1 journals, 35\% of empirical articles use secondary data sources, much higher than in lower-tier journals (Tier 2: 27\%; Tier 3: 10\%; Tier 4: 9\%). Where authors used primary data and excluding seven articles where the sample size was over 1500 , the sample sizes had mean 268 and median 127. This is a slightly larger median size than returned by Boyd et al., (2005) in their earlier examination of strategic management research.

\section{Analytical Methods}

Quantitative analysis dominates the SE research domain - of the 410 empirical articles, 263 (64\%) employed quantitative techniques, and 147 (36\%) employed qualitative techniques. For quantitative articles, an examination of the trend over the 11-year period reveals a steady relative

decline in share of publications, from $79 \%$ in 2009 to $62 \%$ in 2019 . While there is an increase in the absolute number of qualitative articles published, the percentage of these continues to average about $25 \%$ of the total number of publications (the difference being made up by articles employing a mixed methods approach). Proportionally more quantitative articles over the period 2009-2019 were published in Tier 1 journals, and in 2017, 83\% of empirical articles in Tier 1 journals employed quantitative techniques. Although a total of 97 case studies were reported, the share of case studies is falling in percentage terms, and case studies are rarely published in Tier 1 journals - only seven (7\%) of case studies were published in Tier 1 journals despite those journals accounting for $14 \%$ of all articles in our sample. Excluding mixed methods and/or single-case study articles, only 44 articles employed qualitative techniques alone. 


\section{Content Analysis and Main Themes}

\section{Keywords}

An analysis of word frequency in each abstract was employed to identify keywords, based on our assumption that if a concept was key to authors' research, the relevant keyword would appear in the keyword list of the article. A manual check was made of each abstract, and in some cases reviewers allocated additional keywords based on the abstract and/or from a subsequent scan of the entire article. Guided by Suddaby (2006) and adapting Gioia et al.'s (2013) approach to data analysis, we looked for common patterns amongst these keywords. Reviewers were able to model different inductive hierarchies using keyword frequency as guidelines to build a taxonomy. Using an iterative, discursive approach, keywords tables were built, ultimately clustering our findings into six main themes. We added weight to certain keywords (built on frequency of use) and these drove the definition of our six main themes. In identifying these six main themes, our intention was not to suggest that themes represent separate fields within SE. Rather, it is to state that authors, editors, and reviewers are writing and publishing articles under the overarching umbrella known as SE whose content is informed by these (often overlapping) major themes.

\section{Main Themes within the SE Domain}

The six main themes that emerged from our analysis of allocated keywords were (i) Sustainable Competitive Advantage; (ii) Knowledge Management; (iii) Ecosystems; (iv) Strategy; (v) Entrepreneurialism; and (vi) Organization and Management. Note that, while each keyword was assigned to a single thematic category, each article was tagged on average with four keywords, such that any article may be assigned to, and thus have effectively partial membership of, more than one thematic category rather than being entirely located in a single category, which is to be expected for a within-domain study where the subdomains are interrelated. In naming our main 
themes, we were guided by the keywords allocated to that theme. Table 1 shows the keywords associated with each of the main themes.

\section{Sustainable Competitive Advantage (SCA) (249 articles)}

We define sustainable competitive advantage as the survival and continued success of the firm attained through innovation and increased competencies to drive firm performance. This definition was guided using the construct in mainstream literature and its congruence with the keywords allocated to this major theme. Articles allocated to this theme examine how resources - such as firm performance (e.g., Hmieleski et al., 2012; Wales et al., 2013); the quest for success (e.g., Tomy and Pardede, 2018); survival (e.g., Huggins et al., 2017); and how organizations build competitive advantage (e.g., Dunlap-Hinkler et al., 2010) through innovation and appropriation (e.g., Pandher et al., 2017). The keywords of "firm performance" and "competitive advantage" and "success" predominate in this main theme, with more negative outcomes - such as "bankruptcy" (e.g., Gailly et al., 2015) or "failure" (e.g., Shepherd and Haynie, 2011; Wiklund and Shepherd, 2011) being only found occasionally. Hereafter, in the interests of parsimony, all references to articles under the heading of a theme or topic should be understood as examples of articles addressing that theme or topic.

\section{Knowledge Management (333 articles)}

Our inductive definition for this theme is the management of knowledge by firms - whether through creation, acquisition, retention, or utilization - successfully predicting and fostering learning, technology transfer, and research and development to create intellectual property. This necessitates the building of reciprocal knowledge flows within the firm's social network - using knowledge spill-over and spill-in opportunities - to boost the contribution of social capital through a process of sensemaking and feedback to increase entrepreneurial knowledge. Articles falling under this main theme were those tagged with keywords that described the intent of processing and 
applying that knowledge. Interaction with external parties is the first step in the process of knowledge management, and firms achieve this through active means such as management research (yrgidou and Hughes, 2010); feedback (Bloodgood et al., 2015; Connelly et al., 2011; Snihur et al., 2017); technology transfer (Li, 2018; Powell and Sandholtz, 2012; Priem et al., 2012); or knowledge spillover (Siegel and Wright, 2015; Vissa and Chacar, 2015). Successful firms utilize their social capital or social network to acquire market knowledge. Once acquired, these are then managed (Anderson et al., 2009; Sirén et al., 2012) through processes of sensemaking (Wood and McKinley, 2010) and predication (Keupp and Gassmann, 2009), and as a research and development efforts (Filatotchev and Piesse, 2009; Powell and Sandholtz, 2012) are retained by protecting the firm's intellectual property (Autio and Acs, 2010; Gordon et al., 2012).

\section{Ecosystems (374 articles)}

A firm's ecosystem is defined as the network and environment in which the firm operates, comprising elements relating to finance, culture, infrastructure, human capital, markets, and government policies. In emerging markets or those working at the bottom of the pyramid (perhaps in the informal sector), clusters of firms can boost economic development, enhance sustainability, and counteract crises (often encouraged by government policies). Whether in a developing country (Obeng et al., 2014), or in an emerging (Yu et al., 2013) or mature economy, firm performance is heavily influenced by the environmental dynamism (Carnahan et al., 2012; Hanson and Blake, 2009) and culture (Eddleston et al., 2012; Webb et al., 2011) of its immediate ecosystem. Concepts such as sustainability (Michelon and Parbonetti, 2012; Weerawardena et al., 2010) and environmentalism (Lin and Si, 2014; Wallace et al., 2015) are two examples of cultural influence on firms' ecosystems. Government policies (Levie and Autio, 2011; Spigel and Harrison, 2018) aim to strengthen ecosystems (Hsieh et al., 2009; de Vasconcelos Gomes et al., 2018) for the purposes of economic development. Whether operating in the informal (De Castro et al., 2014; 
$\underline{\text { Ramirez and Hondagneu-Sotelo, 2009) }}$ or formal sector, or at the bottom of the pyramid (Dolan and Rajak, 2016), government promote clusters (Huggins and Thompson, 2015; Powell and

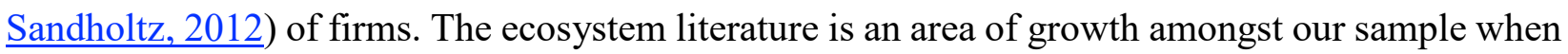
viewed across all journals.

Strategy (349 articles)

Strategy is defined as the collective decision making made by the top management team (TMT) of the firm that is intended to deliver the firm's current and future goals. At an early stage, entrepreneurs need to decide on the market orientation of the firm - perhaps to aim for growth in international markets (born global [ipipolles et al., 2012], or transnational entrepreneurs [Patel and Terjesen, 2011]) or alternatively to focus on niche markets (Midtbøen and Nadim, 2019). At a more mature stage in the firm's life cycle, with a greater understanding of competitor activity and the environment in which the firm is operating, entrepreneurs may undertake more transformative strategies, through strategic renewal (Shu et al., 2019). At this stage, whether to diversify (Pierce and Aguinis, 2013) or pivot (Civera et al., 2019) to new markets becomes relevant. Finally, the TMT may need to decide when and if to take the firm to an initial public offering (Payne et al., 2013), to spin-off (Berchicci et al., 2011) certain parts of the business, to merge (Mason and Weeds, 2013) with other entities, or to invest in buyouts (Meuleman et al., 2009), acquisitions, to develop a portfolio of companies (Baert et al., 2016), or even exit (Mason and Weeds, 2013) the business.

In the internet age, international barriers are less of an obstacle for entrepreneurs, and the literature reflects these changes in international entrepreneurship (Bruneel et al., 2010; Dai et al., 2014; Keupp and Gassmann, 2009) with transnational entrepreneurs (Patel and Terjesen, 2011; Zolin and Schlosser, 2013) becoming an increasing focus for researchers. Such opportunities offer new avenues for decision-makers (Eddleston et al., 2012; Hodgkinson et al., 2009); an avenue to 
avoid competitors (Brouthers et al., 2014; Carnahan et al., 2012; Seilov, 2015); competitive intensity (Martin and Javalgi, 2016); adopt new strategies (De Clercq et al., 2014; Ott et al., 2017); and change the context (Ngoasong, 2018) of the organization. In resource-scarce environments (Welter et al., 2018), firms are often required to move through a process of strategic renewal (Bierwerth et al., 2015; Kraus et al., 2011; Lau and Bruton, 2011); to orientate to new markets (Gruber et al., 2013; Ripolles et al., 2012); using new marketing strategies (Bizzi and Langley, 2012; Martin and Javalgi, 2016) or new goals (Amit and Zott, 2015; Vissa and Chacar, 2009); and explore new areas for growth (Bjørnskov and Foss, 2013; Drnovsek et al., 2016). This may involve diversification (Gruber et al., 2013; Pierce and Aguinis, 2013), or adjusting the portfolio (Sieger et al., 2011) of firms through buyouts (Meuleman et al., 2009) and mergers (Walsh and Linton, 2011). Over the life cycle (Lungeanu and Zajac, 2016) of the firm, researchers not only look at strategies at birth (for example, born global firms [Onetti et al., 2012]), but also other milestone events such as an initial public offering (Chaddad and Reuer, 2009), or entrepreneurial exit (Mason and Weeds, 2013).

\section{Entrepreneurialism (419 articles)}

We define entrepreneurialism as the behavior associated with entrepreneurial action and the motivations that precede this behavior. Since firms per se cannot have motivations we refer to the motivations of individual entrepreneurs and/or the top management team who guide firm-level behavior (Hambrick and Mason 1994). Entrepreneurialism includes the entrepreneurial process and the capabilities of the entrepreneur and the opportunity nexus - opportunity exploration and opportunity exploitation. At the level of the individual, we include the personality of the entrepreneur, gender, creativity, self-efficacy, age, motivation, resourcefulness, resilience, passion, beliefs, intention, mindset, values, optimism, and imagination. Finally, entrepreneurialism also 
encompasses different types of entrepreneurship, for example, social entrepreneurship and serial entrepreneurship.

The literature that examines the behavior associated with entrepreneurial action can be split into two main parts - those that deal with the characteristics that define the entrepreneurial individual (Fornoni et al., 2011; van Ness and Seifert, 2016) or corporate actor (Carnahan et al., 2012, Rigtering and Weitzel, 2013), and those that examine all or part of the entrepreneurial process (Pryor et al., 2016), from opportunity seeking (Kyrgidou and Hughes, 2010) - whether via creation (Welter et al., 2016), exploration (Sirén et al., 2012), or recognition - to opportunity exploitation.

When examining the entrepreneur as an individual, researchers examine the individual's beliefs (Felin and Zenger, 2009); capabilities (Abdelgawad et al., 2013); personality (Smith et al., 2018); creativity (Scott et al., 2010); gender (García and Welter, 2013; Hanson and Blake, 2009); imagination (Miller and Le Breton-Miller, 2017); mindset (Jabeen et al., 2017); immigrant status (Zolin and Schlosser, 2013); motivation (Rigtering and Weitzel, 2013); optimism (Dawson, 2017); passion (Drnovsek et al., 2016); resilience and resourcefulness (Hmieleski et al., 2015); selfefficacy (Cassar and Friedman, 2009); intentions (Lin and Si, 2014); behavior (Dew et al., 2009); capability (Abdelgawad et al., 2013); self-employment (Chang et al., 2012); serial entrepreneurship (Lin et al., 2019); and values (Poblete, 2018).

Secondly, the literature on the entrepreneurial process examines the act of entrepreneuring (Kyrgidou and Hughes, 2010), and the processes entailed in this act (Pryor et al., 2016), from origination (Shams and Kaufmann, 2016) and innovation (Dunlap-Hinkler et al., 2010), to commercialization (Walsh and Linton, 2011) and considering sources of funds, such as venture capital (Dushnitsky and Lavie, 2010; Meuleman et al., 2009; Wiltbank et al., 2009), and crowdfunding (Gafni et al., 2019). 
Organization \& Management (459 articles)

Organization and Management is the system of governance that builds the linkages between the firm's internal and external activity. These structures include the business model employed by the leadership of the firm - its upper echelons, top management team, or board - and the ways in which it interacts with stakeholders. Internally, organizational structures require flexibility and a degree of slack to innovate and respond to new opportunities, whether through the collaborative action of teams or individuals and deliver essential functions such as new product development, or marketing and process innovations.

The firm's business model (Kim and Min, 2015; Sorrentino and Garraffo, 2012; Williams and Lee, 2009; Yang et al., 2010), creates the overall structure of internal and external systems which govern the operation of the firm. Internal systems are developed to facilitate leadership (Kansikas et al., 2012; Yan et al., 2014), governance (Meuleman et al., 2009; Sahaym et al., 2016), influenced by the composition of the board (Michelon and Parbonetti, 2012), or top management team (Chen and Nadkarni, 2017). Human capital (Eddleston et al., 2012) is critical to a firm's administrative systems and the literature examines structures (Khaire, 2010), the use of professional managers (Au et al., 2013), or how previous career paths (Engel et al., 2017) shape entrepreneurial managers. Teams play a vital role in the structure of firms, whether at start-up (Klotz et al.,2014) or through linkages to the external network (Vissa and Chacar, 2009). External social networks - through the influence of stakeholders (Burns et al., 2016; Shams and Kaufmann, 2016) - can help drive strategic flexibility (Fernandez Perez et al., 2013). Organizations collaborate (Vural et al., 2013) via alliances (Moghaddam et al., 2016) with other firms. Finally, the standing of the firm in the local community, and its level of corporate social responsibility (Alonso and Austin, 2018) are involved in this main theme. 


\section{Interplay between Themes and Trends in the Literature}

Through an examination of trends in the literature, three of the above six themes have seen a steady number of publications during the period of our analysis. Growth in the literature has emerged from articles on Ecosystems, Organization \& Management and Entrepreneurialism. Research into the character of the entrepreneur is on the increase, whether relating to motivational drivers (resulting in an increase in social entrepreneurship) or cultural forces (for example, gender differences). For the Organization \& Management theme, this period has seen increasing diversification of subthemes in the literature, matched by an increase in the number of articles. In 2009, governance was a major keyword in the sample, but this has largely disappeared in more recent years. The Ecosystem literature is one of the largest growth areas, with the role of the network featuring strongly in articles. This literature has also seen an increase in diversity, examining the ecosystem with a greater awareness of the context in which the ecosystem sits.

\section{Discussion and Research Agenda}

During our qualitative analysis of articles in the SE domain, we noticed three major areas that provide opportunities for future research, namely the boundaries of the strategic entrepreneurship construct, the importance of context, and the methodological approach to data selection and analysis.

\section{Construct Definition}

Within the body of literature reviewed in this paper, the construct of strategic entrepreneurship lacks contextual definition arising from a lack of clarity as to when and where the act of entrepreneuring occurs. Appropriate (or possible) strategies in a start-up venture are very different from those appropriate within an established firm. This raises the question, at what point does the 
firm shift from being an individual entrepreneur's new venture, to an established firm practicing corporate entrepreneurship (Carpenter et al., 2004; Hambrick and Mason, 1984)?

While entrepreneurial behavior can be exhibited at both the individual or organizational level, we believe the SE construct can fruitfully be delineated from entrepreneurial behavior at the individual level, which has a vast literature focusing on the attitudes, abilities, and behaviors of individual entrepreneurs. We advocate that a useful boundary condition for the future SE construct would be its limitation to organizational-level strategic entrepreneurship. This answers Simsek et al. 's (2017) call for a boundary condition on SE. As stated initially, the SE domain is located at the intersection of strategic management (of existing organizations) and entrepreneurialism - i.e., the entrepreneurial behavior of an entity. A subset of SE is where the focal organization is a commercially oriented business firm, where it is known as corporate entrepreneurship (Kotha, 2010). Other (not necessarily corporate) organizations practicing SE include social purpose ventures, public sector organizations, and national governments.

Rapid technological change is forcing managers of almost all organizations to rejuvenate their product and service offerings to keep pace with rivals who are utilizing newer technology and/or are more in tune with their customers' or constituents' demands. Of course, firms and other organizations do not act without the guidance and direction of human decision makers, but future SE research might be usefully confined to individual and team decision making that underlies the behavior of existing organizations (Hambrick and Mason 1984) rather than the decision making of individuals and teams contemplating new venture formation or the early establishment and growth phases of new entrepreneurial ventures. We find that authors, editors, and reviewers have regarded strategic entrepreneurship as the act of entrepreneuring to develop strategies that deliver a sustainable competitive advantage where knowledge management and organizational management systems are perceived as critical influencers of strategy, moderated by the external ecosystem. 
However, in much of the domain, research lacks a holistic approach and fails to explore how strategies are moderated by the external ecosystem. Opportunities are situational and can be "better understood within [their] historical, temporal, institutional, spatial, and social context" (Welter, 2011; see also Johns, 2006). This results in a failure to ground findings within the context of the research and overlooks the effects of the industry in which the firm operates, and its age, and its size.

A clearer delineation of individual entrepreneurship from organizational entrepreneurship would enable a better understanding of how strategies alter at distinct stages of a firm's growth or in a different industry context. Within our samples, 111 articles were specifically tagged with corporate entrepreneurship, but only 35 of these articles specifically referenced the context in which corporate entrepreneurship is taking place (viz: multinational firms, 12; small and medium enterprises, 15; family firms, 7; and franchising, 1). Because context modifies the ability of entrepreneurs to build strategic competitive advantage, future researchers should provide greater clarity about the industry or sector in which the firm or organization is located.

\section{Research Context}

\section{Market Conditions}

Of the 278 industry-based research projects in this review, 164 researched multiple industries. Yet each industry is subject to situational forces that moderate the effectiveness of any chosen entrepreneurial strategy. Instability and extreme conditions create alternate SE behaviors and activities not necessarily located in growing, high-tech industries where incumbents experience a "munificence" of resources (Castrogiovanni, 1991) and "organizational slack" (Nohria and Gulati, 1996). Only 33 articles specifically referred to market dynamism in the markets in which the firm operates. We found even fewer references to adverse environments which threaten the firm's survival - for example, only five articles were tagged with the keyword "crisis". But technological 
change continually threatens survival through market disruption. While the dynamic capabilities literature (Samson and Lawson 2001; Teece et al., 1997) focuses on large firms' responses to technological disruption (Molina-Morales et al., 2019; Urbano et al., 2019; Xie et al., 2018), there is little research on the strategies employed by small and medium sized enterprises (SMEs) that allow them to survive in technologically disrupted industries (Nag et al., 2020). Most entrepreneurship research focuses on the disruptor rather than on the disrupted. There is much scope for SE research in the context of "non-munificent" and "exhausted organizational slack" faced by SME firms suffering technological disruption.

Similarly, within our sample, research is plentiful where high profits and growth predominate. While "firm performance" was tagged more than any other keyword (93 times), and the word "success" was tagged 71 times, the word "failure" was tagged only 18 times. Given the business failure rates, particularly among smaller firms, this imbalance in the literature represents a divergence from the reality faced by practitioners. Other contexts that have had limited research include SE in extreme conditions including regions and places experiencing military or social conflict, or regions and places facing extreme circumstances because of natural disasters, uncontained pandemics, or contexts experiencing hyperinflation, and similar events that traumatize economic and social stability including constant shifts of customer preferences.

\section{Firm Age}

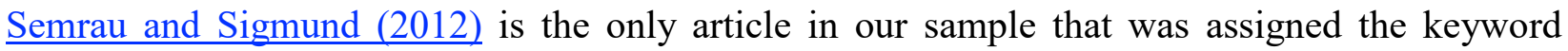
"mature firms". As firms mature, they must practice ongoing strategic entrepreneurship to gain, maintain, or renew their competitive advantage. Markets change and opportunities are explored and exploited, even in mature markets and by mature organizations. 


\section{Firm size}

Of the 396 (68\%) empirical research articles, only one in five referenced the size of the firms under study. The lack of specification of firm size is problematic, as firms of different sizes have access to different resources, and available resources shape what strategies are possible for management teams. The absence of specific mention of firm size may lead the reader to implicitly equate notions of "entrepreneurial" with "small firm".

\section{Public or State Sector}

Increasingly, larger private-sector organizations are recognizing the benefit of utilizing the entrepreneurial skills of their workforce. This contrasts with the general apathy and lack of innovativeness in larger public-sector organizations where risk taking is not encouraged and innovations are not induced by competition. This review revealed 111 articles on corporate entrepreneurship but research into entrepreneurial activity in the public or state sector remains in its infancy with only six articles in this review of the literature addressing this issue.

\section{Operational Awareness}

Strategic entrepreneurship sees the employment of a multiplicity of strategies interacting with each other. Research on one strategy in isolation fails to take account the interaction between strategies, which - given the context of the research - may reinforce or counteract. Many of the studies in our sample examined strategies in isolation and did not take a holistic view of the multiplicity of strategies employed by entrepreneurs. As a result, strategic efficacy is often measured in the average, and does not examine the case level which better represents practitioner's experience.

\section{Data Sources}

While secondary data adds rigor to the research, it may limit the extent to which the author can create new insights. Interacting with actual entrepreneurs and placing greater emphasis on primary data sources facilitates revelation of what is happening "at the coalface" and is recommended for 
researchers seeking to conduct SE research that is more interesting and more relevant (Shepherd and Wiklund, 2009). Journal editors are likely to be more receptive to quantitative articles with interesting new datasets than to yet another paper using a familiar secondary data source that has already been farmed extensively. Collecting primary data is time consuming and expensive, but it is a pathway to original research.

Grounded research, or qualitative case-study analysis of a single firm or small number of firms' SE behavior is also recommended. As noted, we found relatively few qualitative case studies, and most of these were not published in Tier 1 journals, whose quality thresholds for case studies were apparently met only infrequently. Grounded research offers the opportunity to discover entrepreneurial behaviors inconsistent with prior theories, and via abductive theory building (Shepherd and Suddaby, 2017) to make important contributions to new theory. As entrepreneurial practice continues to evolve, entrepreneurial theory lags practice, and thus journal content will tend to lag real world experience. Accordingly, we urge scholars, reviewers, and editors to consider more grounded theory building qualitative studies in the SE domain.

Cross-sectional analysis cannot unequivocally "prove or disprove" hypotheses: they can only "support or not support" hypotheses, because observation of the causal and the outcome variables in the same time frame may provide simply coincidental relationships rather than evidence that than one variable caused the other, or there may be reverse causality rather than the hypothesized direction of causality. Strict proof of hypothesized data relationships requires longitudinal data collection, with the causal variables collected first and the focal outcome data collected after an appropriate time lag (Headd and Kirchhoff, 2009). Collection of longitudinal data requires careful preparation and patience but spreads the data collection task over an extended period during which the researcher can work on alternative projects. In our sample, only 22 articles employed longitudinal data collection, and editors are consistently calling for the greater use of 
longitudinal data, so we recommend that researchers invest in longitudinal datasets to produce more conclusive quantitative support for their hypotheses and consequently build better theories. Alternatively, data that may offer more reliable proof of causality may be collected using experimental methods (Salerno et al., 2015).

\section{Analytic Methods}

The overwhelming majority of empirical papers in our sample employed traditional symmetric correlational methods, such as multiple regression analysis, when analyzing data. These assume data symmetry and are unable to include more than a few interactive effects between variables (Woodside, 2013). Correlational methods provide a sample-level overview of the causes that are common across respondents and as such are suitable for population-level analyses that can rely on sample-average data, such as public policy interventions, entrepreneurial education initiatives, and inter-industry and international comparisons. They are appropriate for large datasets where the researcher seeks to find the dominant net effects. But as Maula and Stam (2020) caution, the analytical method must be congruent with the phenomenon under study. In the domain of SE, the researcher's interest is often to explain the behavior of the individual or firm or at the case level. Traditional analytical methods are not designed to reveal case-level complexities evident in the entrepreneurial behavior of individual people or firms. It does not reveal asymmetries, data interdependency, and the equifinality of multiple pathways to a desired outcome.

Fuzzy-set Qualitative Comparative Analysis (fsQCA) is a fast-emerging new method that is congruent with the characteristics of entrepreneurial behavior (see, e.g., Douglas et al., 2020; Fiss, 2011; Furnari et al., 2020; Misangyi et al., 2017; Ragin 2008). It is a method that can explain the "complex causality" (Furnari et al., 2020) of entrepreneurial behavior (see, e.g., Douglas et al., 2020). FsQCA allows a more holistic insight into the combinations of entrepreneurial strategies employed by entrepreneurs and their firms, providing a more granular analysis that can reveal a 
multiplicity of configurations that result in the same outcome. FsQCA also facilitates abductive theory building which allows an iterative process of inductively seeking to identify within-case data relationships, to observe empirical anomalies (results at variance with extant knowledge), and to subsequently extend configural models to include missing variables expected to explain observed anomalies. Adopting this newer analytical method will allow researchers to better analyze the effects of such multiple strategies simultaneously employed in strategic entrepreneurship. Only two studies in our sample utilized fsQCA (McKenny et al., 2018; Smith et al., 2018), indicating there is clearly much scope for its application in the SE domain. It is relatively easy to learn and apply, and increasingly journals will be expecting this method, alone or as a complement to correlational analysis, for studies that seek to explain the complex causality of individual or firmlevel entrepreneurial behavior.

\section{Dynamism of the Main Themes}

Examining trends in the themes identified above shows an increasing awareness amongst authors and editors of the importance of context in studies. Diversified perspectives on the Ecosystems literature, and more contextual awareness in the Organization \& Management themes reflect the broadening and deeper understanding of these concepts. By way of contrast, the Strategy theme literature and literature on Sustainable Competitive Advantage lacks similar content diversification. This suggests new insights can emerge from the literature if similar contextual approaches were adopted by researchers examining these two main themes.

\section{Summary, Implications, and Limitations}

In this article we have conducted a meta-data driven, systematic quantitative analysis of the SE research literature for articles published in the period 2009-2019 inclusive. Our analysis identified six main themes in the literature and revealed areas for further research in the domain. We found 
evidence of a widening field of strategic entrepreneurship as researchers in fields tangential to strategy and entrepreneurship, such as tourism management, sports management, and other applied management areas recognize the relevance of the domain to their research field. There has been growth not only in the number of articles, but also in the number and type of journals in which the articles were published. As the domain of SE has matured, the ratio of conceptual and literature review-based articles has increased as those involved in the discipline seek to define the field more closely. We conclude that the boundaries of strategic entrepreneurship appear to be highly permeable.

\section{Contributions of this Research}

This article makes several main contributions to entrepreneurship research. First, we have scoped out the domain of strategic entrepreneurship as it has evolved under the guidance of scholars, editors, and reviewers. We argue that within the broader entrepreneurship literature, SE is a domain largely separate from individual entrepreneurship, focusing on organizational-level behavior that occurs beyond the pre-startup and early establishment and growth phases of individual-level entrepreneurship, notwithstanding that individuals and management teams make the decisions that underlie the behavior of established firms. Second, we have identified, using a bottom-up inductive bibliometric process, six major thematic areas that characterize the SE domain. These main themes overlap and in many cases new research oriented to any one of these thematic areas should recognize the covariance with and implications for the other thematic areas. Third, we have observed and noted a variety of trends that evolved over the 2009-2019 period, relating to paper types, co-author numbers, differences according to journal tiers, and other matters. Finally, we offer a range of ideas for future research in the SE domain. 


\section{Limitations}

This study is not without its limitations, some of which are related to the methodology used. Our intention in this article was to use a systematic bibliometric approach to reveal what authors, editors and reviewers consider as included in the SE domain based on an extensive review of as wide a body of literature from the field as possible. We prioritized transparency and reproducibility of the results over ad hoc inclusions of papers known to the reviewers. Given our strict methodological rigor, we recognize that omission of excellent articles is inevitable. Therefore, our observations and comments are made only using results from this dataset - not from a more subjective view of the wider literature. Alternative systematic reviews of the SE literature, using different search terms, would return different results, but given our very large sample size, we believe we have captured the essence of the SE domain in this study. 


\section{References}

Abdelgawad, S. G., Zahra, S. A., Svejenova, S. \& Sapienza, H. J. (2013). Strategic Leadership and Entrepreneurial Capability for Game Change, Journal of Leadership and Organizational Studies, 20 (4), pp394-407.

Alonso, A. D. \& Austin, I. P. (2018). Entrepreneurial CSR, managerial role and firm resources: a case study approach, Competitiveness Review, 28 (4), pp368-385.

Amit, R. \& Zott, C. (2015). Crafting Business Architecture: the Antecedents of Business Model Design, Strategic Entrepreneurship Journal, 9 (4), pp331-350.

Anderson, B. S., Covin, J. G. \& Slevin, D. P. (2009). Understanding the relationship between entrepreneurial orientation and strategic learning capability: an empirical investigation, Strategic Entrepreneurship Journal, 3 (3), pp218-240.

Au, K., Chiang, F. F., Birtch, T. A. \& Ding, Z. (2013). Incubating the next generation to venture: The case of a family business in Hong Kong, Asia Pacific Journal of Management, 30 (3), pp749-767.

Autio, E., \& Acs, Z. (2010). Intellectual property protection and the formation of entrepreneurial growth aspirations, Strategic Entrepreneurship Journal, 4(3), pp234-251.

Baert, C., Meuleman, M., Debruyne, M. \& Wright, M. (2016). Portfolio Entrepreneurship and Resource Orchestration, Strategic Entrepreneurship Journal, 10 (4), pp346-370.

Berchicci, L., King, A. A. \& Tucci, C. L. (2011). Does the apple always fall close to the tree? The geographical proximity choice of spin-outs, Strategic Entrepreneurship Journal, 5 (2), pp120136.

Bierwerth, M., Schwens, C., Isidor, R. \& Kabst, R. (2015). Corporate entrepreneurship and performance: A meta-analysis, Small Business Economics, 45 (2), pp255-278.

Bizzi, L. \& Langley, A. (2012). Studying processes in and around networks, Industrial Marketing Management, 41 (2), pp224-234.

Bjørnskov, C. \& Foss, N. J. (2013). How Strategic Entrepreneurship and The Institutional Context Drive Economic Growth, Strategic Entrepreneurship Journal, 7 (1), pp50-69.

Bloodgood, J. M., Hornsby, J. S., Burke, A. \& Sarooghi, H. (2015). A system dynamics perspective of corporate entrepreneurship, Small Business Economics, 45 (2), pp383-402.

Boyd, B. K., Toms, S., \& Hitt, M. A. (2005). Construct Measurement in Strategic Management Research: Illusion or Reality? Strategic Management Journal, 26, pp239-257.

Brouthers, K. D., Nakos, G. \& Dimitratos, P. (2014). International Alliances with Competitors and Non-Competitors: The Disparate Impact on Sme International Performance, Strategic Entrepreneurship Journal, 8 (2), pp167-182.

Bruneel, J., Yli-Renko, H. \& Clarysse, B. (2010). Learning from experience and learning from others: how congenital and interorganizational learning substitute for experiential learning in young firm internationalization, Strategic Entrepreneurship Journal, 4 (2), pp164-182.

Burns, B. L., Barney, J. B., Angus, R. W. \& Herrick, H. N. (2016). Enrolling Stakeholders under Conditions of Risk and Uncertainty, Strategic Entrepreneurship Journal, 10 (1), pp97-106.

Busenitz, L. W., West III, G. P., Shepherd, D. A., Nelson, T., Chandler, G. N. \& Zacharakis, A. (2003). Entrepreneurship Research in Emergence - Past Trends and Future Directions, Journal of Management, 29(3), pp285-308.

Carnahan, S., Agarwal, R. \& Campbell, B. A. (2012). Heterogeneity in turnover: the effect of relative compensation dispersion of firms on the mobility and entrepreneurship of extreme performers, Strategic Management Journal, 33 (12), pp1411-1430. 
Carpenter, M. A., Geltkanycz, M. A. \& Saunders, W. G. (2004). Upper Echelons Research Revisited: Antecedents, Elements, and Consequences of Top Management Team Composition, Journal of Management, 30 (6), pp749-778.

Cassar, G. \& Friedman, H. (2009). Does self-efficacy affect entrepreneurial investment? Strategic Entrepreneurship Journal, 3 (3), pp241-260.

Castrogiovanni, G. (1991). Environmental Munificence: A theoretical assessment, Academy of Management Review, 16 (3), pp542-565.

Chaddad, F. R. \& Reuer, J. J. (2009). Investment dynamics and financial constraints in IPO firms, Strategic Entrepreneurship Journal, 3 (1), pp29-45.

Chang, Y., Chen, M., Lin, Y. \& Gao, Y. (2012). Measuring Regional Innovation and Entrepreneurship Capabilities, Journal of the Knowledge Economy, 3 (2), pp90-108.

Chen, J. \& Nadkarni, S. (2017). It's about Time! CEOs' Temporal Dispositions, Temporal Leadership and Corporate Entrepreneurship, Administrative Science Quarterly, 62 (1), pp3166.

Civera, A., Donina, D., Meoli, M. \& Vismara, S. (2019). Fostering the creation of academic spinoffs: does the international mobility of the academic leader matter? International Entrepreneurship and Management Journal, 15 (1), pp1-27.

Connelly, B. L., Certo, T. S., Ireland, R. D. \& Reutzel, C. R. (2011). Signaling Theory: A Review and Assessment, Journal of Management, 37 (1), pp39-67

Dai, L., Maksimov, V., Gilbert, B. A. \& Fernhaber, S. A. (2014). Entrepreneurial orientation and international scope: The differential roles of innovativeness, proactiveness, and risktaking, Journal of Business Venturing, 29 (4), pp511-524.

Davidsson, P., (2014). Entrepreneurial Growth. In D. Kuratko \& M. Morris, The Wiley Encyclopedia of Management (3rd Ed), Volume III: Entrepreneurship. Wiley.

Dawson, C. (2017). Financial Optimism and Entrepreneurial Satisfaction, Strategic Entrepreneurship Journal, 11 (2), pp171-194.

De Castro, J. O., Khavul, S. \& Bruton, G. D. (2014). Shades of Grey: How do Informal Firms Navigate Between Macro and Meso Institutional Environments? Strategic Entrepreneurship Journal, 8 (1), pp75-94.

De Clercq, D., Zhou, L. \& Wu, A. (2016). Unpacking the relationship between young ventures' international learning effort and performance in the context of an emerging economy, International Entrepreneurship and Management Journal, 12 (1), pp47-66.

de Vasconcelos Gomes, L. A., Facin, A. L., Salerno, M. S. \& Ikenami, R. K. (2018). Unpacking the innovation ecosystem construct: Evolution, gaps and trends, Technological Forecasting and Social Change, 136, pp30-48.

Dew, N., Sarasathy, S., Read, S. \& Wiltbank, R. (2009). Affordable loss: behavioral economic aspects of the plunge decision, Strategic Entrepreneurship Journal, 3 (2), pp105-126.

Dolan, C. \& Rajak, D. (2016). Remaking Africa's Informal Economies: Youth, Entrepreneurship and the Promise of Inclusion at the Bottom of the Pyramid, The Journal of Development Studies, 52 (4), pp514-529.

Douglas, E. J., Shepherd, D. A. and Prentice, C. (2020). Using fuzzy-set qualitative comparative analysis for a finer-grained understanding of entrepreneurship, Journal of Business Venturing, 35, pp105970.

Drnovsek, M., Cardon, M. S. \& Patel, P. C. (2016). Direct and Indirect Effects of Passion on Growing Technology Ventures, Strategic Entrepreneurship Journal, 10 (2), pp194-213. 
Dunlap-Hinkler, D., Kotabe, M. \& Mudambi, R. (2010). A story of breakthrough versus incremental innovation: corporate entrepreneurship in the global pharmaceutical industry, Strategic Entrepreneurship Journal, 4 (2), pp106-127.

Dushnitsky, G. \& Lavie, D. (2010). How alliance formation shapes corporate venture capital investment in the software industry: a resource-based perspective, Strategic Entrepreneurship Journal, 4 (1), pp22-48.

Eddleston, K. A., Kellermanns, F. W. \& Zellweger, T. (2012). Exploring the Entrepreneurial Behavior of Family Firms: Does the Stewardship Perspective Explain Differences? Entrepreneurship Theory and Practice, 36 (2), pp347-367.

Engel, Y., van Burg, E., Kleijn, E. \& Khapova, S. N. (2017). Past Career in Future Thinking: How Career Management Practices Shape Entrepreneurial Decision Making, Strategic Entrepreneurship Journal, 11 (2), pp122-144.

Felin, T. \& Zenger, T. R. (2009). Entrepreneurs as theorists: on the origins of collective beliefs and novel strategies, Strategic Entrepreneurship Journal, 3 (2), pp127-146.

Fernandez Perez, V., Verdú-Jóver, A. J. \& Benitez-Amado, J. (2013). Managerial social networks and strategic flexibility: the role of strategic orientation, Personnel Review, 42 (2), pp134-153.

Filatotchev, I. \& Piesse, J. (2009). R\&D, internationalization and growth of newly listed firms: European evidence, Journal of International Business Studies, 40 (8), pp1260-1276.

Fiss, P. C. (2011). Building Better Causal Theories: A Fuzzy Set Approach to Typologies in Organization Research, Academy of Management Journal, 54 (2) pp393-420.

Fornoni, M., Arribas, I. \& Vila, J. E. (2011). Measurement of an individual entrepreneur's social capital: a multidimensional model, International Entrepreneurship and Management Journal, 7 (4), pp495-507.

Furnari, S. Crilly, D. Misangyi, V. F., Greckhamer, T., Fiss, P. C. and Aguilera, R. (2020). Capturing Causal Complexity: Heuristics for Configurational Theorizing, Academy of Management Review, May.

Gafni, H., Marom, D. \& Sade, O. (2019). Are the life and death of an early-stage venture indeed in the power of the tongue? Lessons from online crowdfunding pitches, Strategic Entrepreneurship Journal, 13 (1), pp3-23.

Gailly, B., Gbadji, L. A. \& Schwienbacher, A. (2015). International analysis of venture capital programs of large corporations and financial institutions, Entrepreneurship Theory and Practice, 39 (5), pp1213-1245.

García, M. D. \& Welter, F. (2013). Gender identities and practices: Interpreting women entrepreneurs' narratives, International Small Business Journal, 31 (4), pp384-404.

Gioia, D., Corley, K. G., \& Hamilton, A. (2013). Seeking Qualitative Rigor in Inductive Research, Organizational Research Methods, 16, pp15-31.

Gordon, I., Hamilton, E. \& Jack, S. L. (2012). A study of a university-led entrepreneurship education programme for small business owner/managers, Entrepreneurship and Regional Development, 24 (9), pp767-805.

Gruber, M., MacMillan, I. C. \& Thompson, J. D. (2013). Escaping the prior knowledge corridor: what shapes the number and variety of market opportunities identified before market entry of technology start-ups? Organization Science, 24 (1), pp280-300.

Hambrick, D. C. and Mason, P. A. (1984). Upper echelons: The organization as a reflection of its top managers, Academy of Management Review, 9 (2) pp193-206.

Hanson, S. \& Blake, M. (2009). Gender and Entrepreneurial Networks, Regional Studies, 43 (1), pp135-149. 
Headd, B. \& Kirchhoff, B. A. (2009). The Growth, Decline and Survival of Small Businesses - An Exploratory Study of Life Cycles, Journal of Small Business Management, 47 (4), pp531-550.

Hitt, M.A., Ireland, R.D., Camp, S.M., \& Sexton, D.L. (2001). Strategic entrepreneurship: Entrepreneurial strategies for wealth creation, Strategic Management Journal, 22, pp479-491.

Hmieleski, K. M., Cole, M. S. \& Baron, R. A. (2012). Shared Authentic Leadership and New Venture Performance, Journal of Management, 38 (5), pp1476-1499.

Hmieleski, K. M., Carr, J. C. \& Baron, R. A. (2015). Integrating Discovery and Creation Perspectives of Entrepreneurial Action: The Relative Roles of Founding CEO Human Capital, Social Capital, and Psychological Capital in Contexts of Risk Versus Uncertainty, Strategic Entrepreneurship Journal, 9 (4), pp289-312.

Hodgkinson, G. P.Sadler-Smith, E., Burke, L. A., Claxton, G. \& Sparrow, P. R. (2009). Intuition in Organizations: Implications for Strategic Management, Long Range Planning, 42 (3), pp277297.

Hsieh, L. H., Lin, J. L., Fang, S. \& Tsai, F. (2009). The co-evolution of business incubation and national innovation systems in Taiwan, Technological Forecasting and Social Change, 76 (5), pp629-643.

Huggins, R. \& Thompson, P. (2015). Entrepreneurship, innovation and regional growth: a network theory, Small Business Economics, 45 (1), pp103-128.

Huggins, R., Prokop, D. \& Thompson, P. (2017). Entrepreneurship and the determinants of firm survival within regions: human capital, growth motivation and locational conditions, Entrepreneurship and Regional Development, 29 (3), pp357-389.

Ireland, R. D. \& Webb, J. W. (2009). Crossing the great divide of strategic entrepreneurship: Transitioning between exploration and exploitation, Business Horizons, 52 (5), pp469-479.

Jabeen, F., Faisal, M. N. \& Katsioloudes, M. I. (2017). Entrepreneurial mindset and the role of universities as strategic drivers of entrepreneurship, Journal of Small Business and Enterprise Development, 24 (1), pp136-157.

Johns, G. (2006). The essential impact of context on organizational behavior, Academy of Management Review, 31(2), pp386-408.

Kansikas, J., Laakkonen, A., Sarpo, V. \& Kontinen, T. (2012). Entrepreneurial leadership and familiness as resources for strategic entrepreneurship, International Journal of Entrepreneurial Behaviour and Research, 18 (2), pp141-158.

Ketchen, D. J., Ireland, R. D. \& Snow, C. C. (2007). Strategic entrepreneurship, collaborative innovation, and wealth creation, Strategic Entrepreneurship Journal, 1 (3), pp371-385.

Keupp, M. M. \& Gassmann, O. (2009). The Past and the Future of International Entrepreneurship: A Review and Suggestions for Developing the Field, Journal of Management, 35 (3), pp600633.

Khaire, M. (2010). Young and No Money? Never Mind: The Material Impact of Social Resources on New Venture Growth, Organization Science, 21 (1), pp168-185.

Kim, S. K. \& Min, S. (2015). Business Model Innovation Performance: When does Adding a New Business Model Benefit an Incumbent? Strategic Entrepreneurship Journal, 9 (1), pp34-57.

Klotz, A. C., Hmieleski, K. M., Bradley, B. H. \& Busenitz, L. W. (2014). New Venture Teams: A Review of the Literature and Roadmap for Future Research, Journal of Management, 40 (1), pp226-255.

Kotha, S. (2010). Spillovers, spill-ins, and strategic entrepreneurship: America's first commercial jet airplane and Boeing's ascendancy in commercial aviation, Strategic Entrepreneurship Journal, 4 (4), pp284-306. 
Kraus, S., Kauranen, I. \& Reschke, C. H. (2011). Identification of domains for a new conceptual model of strategic entrepreneurship using the configuration approach, Management Research Review, 34 (1), pp58-74.

Kyrgidou, L. P. \& Hughes, M. (2010). Strategic entrepreneurship: origins, core elements and research directions, European Business Review, 22 (1), pp43-63.

Lau, C. M. \& Bruton, G. D. (2011). Strategic orientations and strategies of high technology ventures in two transition economies, Journal of World Business, 46 (3), pp371-380.

Levie, J. \& Autio, E. (2011). Regulatory burden, rule of law, and entry of strategic entrepreneurs: an international panel study, Journal of Management Studies, 48 (6), pp1392-1419.

Li, L. (2018). China's manufacturing locus in 2025: With a comparison of "Made-in-China 2025" and "Industry 4.0", Technological Forecasting and Social Change, 135, pp66-74.

Liberati, A., Altman, D. G., Tetzlaff, C., Mulrow., C., Gøtzsche, P., Ionnidis, J.P.A., Clarke, M., Devereaux, P.J., Kleijnen, J., \& Moher, D. (2009). The PRISMA statement for reporting systematic reviews and meta-analyses of studies that evaluate health care interventions: Explanation and elaboration, PLoS Medicine, 6(7), pp1-28.

Lin, S. \& Si, S. (2014). Factors affecting peasant entrepreneurs' intention in the Chinese context, International Entrepreneurship and Management Journal, 10 (4), pp803-825.

Lin, S., Yamakawa, Y. \& Li, J. (2019). Emergent learning and change in strategy: empirical study of Chinese serial entrepreneurs with failure experience, International Entrepreneurship and Management Journal, 15 (3), pp773-792.

Liñán, F., \& Fayolle, A. (2015). A systematic literature review on entrepreneurial intentions: citation, thematic analyses, and research agenda, International Entrepreneurship and Management Journal, 11, pp907-944.

Lungeanu, R. \& Zajac, E. J. (2016). Venture Capital Ownership as a Contingent Resource: How Owner-Firm Fit Influences IPO Outcomes, Academy of Management Journal, 59 (3), pp930955.

Martin, S. L. \& Javalgi, R. G. (2016). Entrepreneurial orientation, marketing capabilities and performance: The Moderating role of Competitive Intensity on Latin American International New Ventures, Journal of Business Research, 69 (6), p.2040-2051.

Mason, R. \& Weeds, H. (2013). Merger policy, entry, and entrepreneurship, European Economic Review, 57, pp23-38.

Mathias, B. D., McKenny, A. F. \& Crook, T. R. (2018). Managing the tensions between exploration and exploitation: The role of time, Strategic Entrepreneurship Journal, 12 (3), pp316-334.

Maula, M. V. and Stam, W. (2020). Enhancing Rigor in Quantitative Entrepreneurship Research, Entrepreneurship Theory and Practice, 44 (6), pp1059-1090.

McKenny, A. F., Short, J. C., Ketchen, D. J., Payne, G. T. \& Moss, T. W. (2018). Strategic entrepreneurial orientation: Configurations, performance, and the effects of industry and time, Strategic Entrepreneurship Journal, 12 (4), pp504-521.

Meuleman, M., Amess, K., Wright, M. \& Scholes, L. (2009). Agency, Strategic Entrepreneurship, and the Performance of Private Equity-Backed Buyouts, Entrepreneurship Theory and Practice, 33 (1), pp213-239.

Michelon, G. \& Parbonetti, A. (2012). The effect of corporate governance on sustainability disclosure, Journal of Management and Governance, 16 (3), pp477-509.

Midtbøen, A. H. \& Nadim, M. (2019), Ethnic niche formation at the top? Second-generation immigrants in Norwegian high-status occupations, Ethnic and Racial Studies, 42, p.177-195. 
Miller, D. \& Le Breton-Miller, I. (2017). Sources of Entrepreneurial Courage and Imagination: Three Perspectives, Three Contexts, Entrepreneurship Theory and Practice, 41 (5), pp667-675. Misangyi, V. F., Greckhamer, T., Furnari, S., Fiss, P. C., Crilly, D. and Aguilera, R. V. (2017). Embracing Causal Complexity - The Emergence of a Neo-Configurational Perspective, Journal of Management, 43 (1), pp255-282

Moghaddam, K., Bosse, D. A. \& Provance, M. (2016). Strategic Alliances of Entrepreneurial Firms: Value Enhancing Then Value Destroying, Strategic Entrepreneurship Journal, 10 (2), pp153-168.

Molina-Morales, F. X., Martínez-Cháfer, L. \& Valiente-Bordanova, D. (2019). Disruptive technology adoption, particularities of clustered firms, Entrepreneurship and Regional Development, 31 (1), pp62-81.

Nag, R., Neville, F. \& Dimotakis, N. (2020). CEO scanning behaviors, self-efficacy, and SME innovation and performance: An examination within a declining industry, Journal of Small Business Management, 58 (1), pp164-199.

Ngoasong, M. Zisuh (2018). Digital entrepreneurship in a resource-scarce context, Journal of Small Business and Enterprise Development, 25 (3), pp483-500.

Nohria, N. \& Gulati, R. (1996). Is slack good or bad for innovation? Academy of Management Journal, 39 (5), pp1245-1264.

Obeng, B. A. \& Haugh, H. (2014). Strategic entrepreneurship and small firm growth in Ghana, International Small Business Journal, 32 (5), pp501-524.

Onetti, A., Zucchella, A., Jones, M. V. \& McDougall-Covin, P. P. (2012). Internationalization, innovation and entrepreneurship: business models for new technology-based firms, Journal of Management and Governance, 16 (3), pp337-368.

Ott, T. E., Eisenhardt, K. M. \& Bingham, C. B. (2017). Strategy Formation in Entrepreneurial Settings: Past Insights and Future Directions, Strategic Entrepreneurship Journal, 11 (3), pp306-325.

Pandher, G. S., Mutlu, G. \& Samnani, A. (2017). Employee-based Innovation in Organizations: Overcoming Strategic Risks from Opportunism and Governance, Strategic Entrepreneurship Journal, 11 (4), pp464-482.

Parida, V., Lahti, T. \& Wincent, J. (2016). Exploration and exploitation and firm performance variability: a study of ambidexterity in entrepreneurial firms, International Entrepreneurship and Management Journal, 12 (4), p.1147-1164.

Patel, P. C. \& Terjesen, S. (2011). Complementary effects of network range and tie strength in enhancing transnational venture performance, Strategic Entrepreneurship Journal, 5 (1), pp5880.

Payne, G. T., Moore, C. B., Bell, R. G. \& Zachary, M. A. (2013). Signaling Organizational Virtue: an Examination of Virtue Rhetoric, Country-Level Corruption, and Performance of Foreign IPOs from Emerging and Developed Economies, Strategic Entrepreneurship Journal, 7 (3), pp230-251.

Pierce, J. R. \& Aguinis, H. (2013). The Too-Much-of-a-Good-Thing Effect in Management, Journal of Management, 39 (2), pp313-338.

Pittaway, L., Robertson, M., Munir, K., Deyner, D. \& Neely, A. (2004). Networking and innovation: a systematic review of the evidence, International Journal of Management Reviews, 5 (3), pp137-168.

Poblete, C. (2018). Growth expectations through innovative entrepreneurship: The role of subjective values and duration of entrepreneurial experience, International Journal of Entrepreneurial Behaviour and Research, 24 (1), pp191-213. 
Powell, W. W. \& Sandholtz, K. W. (2012). Amphibious entrepreneurs and the emergence of organizational forms, Strategic Entrepreneurship Journal, 6 (2), pp94-115.

Priem, R. L., Li, S. \& Carr, J. C. (2012). Insights and New Directions from Demand-Side Approaches to Technology Innovation, Entrepreneurship, and Strategic Management Research, Journal of Management, 38 (1), pp346-374.

Pryor, C., Webb, J. W., Ireland, R. D. \& Ketchen, D. J. (2016). Toward An Integration of the Behavioral and Cognitive Influences on the Entrepreneurship Process, Strategic Entrepreneurship Journal, 10 (1), pp21-42.

Ragin, C. C. (2008), Redesigning Social Inquiry. The University of Chicago Press.

Raisch, S., \& Birkinshaw, J. (2008). Organizational ambidexterity: Antecedents, outcomes, and moderators, Journal of Management, 34(3), pp375-409.

Ramirez, H. \& Hondagneu-Sotelo, P. (2009). Mexican Immigrant Gardeners: Entrepreneurs or Exploited Workers? Social Problems, 56 (1), pp70-88.

Rigtering, J. P. \& Weitzel, U. (2013). Work context and employee behaviour as antecedents for intrapreneurship, International Entrepreneurship and Management Journal, 9 (3), pp337-360.

Ripolles, M., Blesa, A. \& Monferrer, D. (2012), Factors enhancing the choice of higher resource commitment entry modes in international new ventures, International Business Review, 21 (4), p.648-666.

Salerno, M. S.de Vasconcelos Gomes, L. A., da Silva, D. O., Bagno, R. B. \& Freitas, S. L. (2015). Innovation processes: Which process for which project? Technovation, 35, pp59-70.

Sahaym, A., Cho, S. Y., Kim, S. K. \& Mousa, F. (2016), Mixed blessings: How top management team heterogeneity and governance structure influence the use of corporate venture capital by post-IPO firms, Journal of Business Research, 69 (3), p.1208-1218.

Samson, D. \& Lawson, B. (2001). Developing innovation capability in organisations: A dynamic capabilities approach, International Journal of Innovation Management, 5 (3), pp337-400.

Scott, P., Gibbons, P. \& Coughlan, J. (2010). Developing subsidiary contribution to the MNC subsidiary entrepreneurship and strategy creativity, Journal of international management, 16 (4), pp328-339.

Seilov, G. Aidarkulovich (2015). Does the adoption of customer and competitor orientations make small hospitality businesses more entrepreneurial? International Journal of Contemporary Hospitality Management, 27 (1), pp71-86.

Semrau, T. \& Sigmund, S. (2012). Networking Ability and the Financial Performance of New Ventures: A Mediation Analysis among Younger and More Mature Firms, Strategic Entrepreneurship Journal, 6 (4), pp335-354.

Shams, S. M. \& Kaufmann, H. R. (2016). Entrepreneurial co-creation: a research vision to be materialised, Management Decision, 54 (6), pp1250-1268.

Shepherd, D. A. \& Haynie, J. M. (2011). Venture failure, stigma, and impression management: A self-verification, self-determination view, Strategic Entrepreneurship Journal, 5 (2), pp178197.

Shepherd, D. A. \& Wiklund, J. (2019). Simple Rules, Templates, and Heuristics! An Attempt to Deconstruct the Craft of Writing an Entrepreneurship Paper, Entrepreneurship Theory and Practice, 44 (3), pp371-390.

Shepherd, D. A. \& Suddaby, R. (2017). Theory Building: A Review and Integration, Journal of Management, 43 (1), pp59-86.

Shu, C., De Clercq, D., Zhou, Y. \& Liu, C. (2019). Government institutional support, entrepreneurial orientation, strategic renewal, and firm performance in transitional China, International Journal of Entrepreneurial Behaviour and Research, 25 (3), pp433-456. 
Sieger, P., Zellweger, T., Nason, R. S. \& Clinton, E. (2011). Portfolio entrepreneurship in family firms: a resource-based perspective, Strategic Entrepreneurship Journal, 5 (4), pp327-351.

Siegel, D. S. \& Wright, M. (2015). Academic Entrepreneurship: Time for a Rethink? British Journal of Management, 26 (4), pp582-595.

Simsek, Z. \& Fox, B. C. (2017). (Meta-)framing strategic entrepreneurship, Strategic Organization, 15 (4), pp504-518.

Sirén, C., Kohtamäki, M. \& Kuckertz, A. (2012). Exploration and exploitation strategies, profit performance, and the mediating role of strategic learning: Escaping the exploitation trap, Strategic Entrepreneurship Journal, 6 (1), pp18-41.

Smith, M. B., Hill, A. D., Wallace, J. C., Recendes, T. \& Judge, T. A. (2018). Upsides to Dark and Downsides to Bright Personality: A Multidomain Review and Future Research Agenda, Journal of Management, 44 (1), pp191-217.

Smith, A. W., Moghaddam, K. \& Lanivich, S. E. (2018). A set-theoretic investigation into the origins of creation and discovery opportunities, Strategic Entrepreneurship Journal, 13 (1), pp75-92.

Snihur, Y., Reiche, B. S. \& Quintane, E. (2017). Sustaining Actor Engagement During the Opportunity Development Process, Strategic Entrepreneurship Journal, 11 (1), pp1-17.

Sorrentino, F. \& Garraffo, F. (2012). Explaining performing R\&D through alliances: Implications for the business model of Italian dedicated biotech firms, Journal of Management and Governance, 16 (3), pp449-475.

Spigel, B. \& Harrison, R. (2018). Toward a process theory of entrepreneurial ecosystems, Strategic Entrepreneurship Journal, 12 (1), pp151-168.

Suddaby, R. (2006). From the editors: What grounded theory is not, Academy of Management Journal, 49, pp633-642.

Teece, D. J., Pisano, G., \& Shuen, A. (1997). Dynamic capabilities and strategic management, Strategic Management Journal, 18(7), pp509-533.

Tomy, S. \& Pardede, E. (2018), From Uncertainties to Successful Start Ups: A Data Analytic Approach to Predict Success in Technological Entrepreneurship, Sustainability, 10 (3), pp602.

Tranfield, D., Denyer, D., \& Smart, P. (2003). Towards a methodology for developing evidenceinformed management knowledge by means of systematic review, British Journal of Management, 14, pp207-222.

Urbano, D., Guerrero, M., Ferreira, J. J. \& Fernandes, C. I. (2019). New technology entrepreneurship initiatives: Which strategic orientations and environmental conditions matter in the new socio-economic landscape? Journal of Technology Transfer, 44 (5), pp1577-1602.

van Ness, R. K. \& Seifert, C. F. (2016). A Theoretical Analysis of the Role of Characteristics in Entrepreneurial Propensity, Strategic Entrepreneurship Journal, 10 (1), pp89-96.

Vissa, B. \& Chacar, A. S. (2009). Leveraging ties: the contingent value of entrepreneurial teams' external advice networks on Indian software venture performance, Strategic Management Journal, 30 (11), pp1179-1191.

Vural, M. O., Dahlander, L. \& George, G. (2013). Collaborative Benefits and Coordination Costs: Learning and Capability Development in Science, Strategic Entrepreneurship Journal, 7 (2), pp122-137.

Yan, H., Chiang, C. \& Chien, C. S. (2014). From original equipment manufacturing to branding: entrepreneurship, strategic leadership, and Taiwan's firm transformation, International Entrepreneurship and Management Journal, 10 (1), pp81-102.

Yang, C., Fang, S. \& Lin, J. L. (2010). Organisational knowledge creation strategies: A conceptual framework, International Journal of Information Management, 30 (3), pp231-238. 
Wales, W., Patel, P. C., Parida, V. \& Kreiser, P. M. (2013). Nonlinear Effects of Entrepreneurial Orientation on Small Firm Performance: The Moderating Role of Resource Orchestration Capabilities, Strategic Entrepreneurship Journal, 7 (2), pp93-121.

Walsh, S. T. \& Linton, J. D. (2011). The Strategy-Technology Firm Fit Audit: A guide to opportunity assessment and selection, Technological Forecasting and Social Change, 78 (2), pp199-216.

Wallace, J. C.Hill, A. D., Baron, R. A., Smith, M. B. \& Johnson, P. D. (2015). A Review of Multilevel Regulatory Focus in Organizations, Journal of Management, 41 (5), pp1501-1529.

Webb, J. W., Allen, J., Morris, M. \& Coombes, S. M. (2011). Behavioural orientations of nonprofit boards as a factor in entrepreneurial performance: does governance matter? Journal of Management Studies, 48 (4), pp829-856.

Welter, C., Mauer, R. \& Wuebker, R. (2016). Bridging Behavioral Models and Theoretical Concepts: Effectuation and Bricolage in the Opportunity Creation Framework, Strategic Entrepreneurship Journal, 10 (1), pp5-20.

Welter, F. (2011). Contextualizing Entrepreneurship - Conceptual Challenges and Ways Forward, Entrepreneurship Theory and Practice, 35 (1), pp165-84.

Welter, F., Xheneti, M. \& Smallbone, D. (2018). Entrepreneurial resourcefulness in unstable institutional contexts: The example of European Union borderlands, Strategic Entrepreneurship Journal, 12 (1), pp23-53.

Weerawardena, J., McDonald, R. E. \& Mort, G. S. (2010). Sustainability of nonprofit organizations: an empirical investigation, Journal of World Business, 45 (4), pp346-356.

Wiklund, J. \& Shepherd, D. A. (2011). Where to From Here? EO-as-Experimentation, Failure, and Distribution of Outcomes, Entrepreneurship Research Journal, 35 (5), pp925-946.

Williams, C. \& Lee, S. H. (2009). Resource allocations, knowledge network characteristics and entrepreneurial orientation of multinational corporations, Research Policy, 38 (8), pp13761387.

Wiltbank, R., Read, S., Dew, N. \& Sarasvathy, S. (2009). Prediction and control under uncertainty: Outcomes in angel investing, Journal of Business Venturing, 24 (2), pp116-133.

Wood, M. S. \& McKinley, W. (2010). The production of entrepreneurial opportunity: a constructivist perspective, Strategic Entrepreneurship Journal, 4 (1), pp66-84.

Woodside, A. G. (2013). Moving beyond multiple regression analysis to algorithms: Calling for adoption of a paradigm shift from symmetric to asymmetric thinking in data analysis and crafting theory, Journal of Business Research, 66, pp463-472.

Wright, M., \& Hitt, M.A. (2017). Strategic entrepreneurship and SEJ: Development and current progress, Strategic Entrepreneurship Journal, 11(3), pp200-210.

Xie, X., Zou, H. \& Qi, G. (2018). Knowledge absorptive capacity and innovation performance in high-tech companies: A multi-mediating analysis, Journal of Business Research, 88, pp289297.

Yu, Y., Dong, X., Shen, K. N., Khalifa, M. \& Hao, J. (2013). Strategies, technologies, and organizational learning for developing organizational innovativeness in emerging economies, Journal of Business Research, 66 (12), pp2507-2514.

Zolin, R. \& Schlosser, F. (2013). Characteristics of Immigrant Entrepreneurs and Their Involvement in International New Ventures, Thunderbird International Business Review, 55 (3), pp271-284.

Note: A full list of articles reviewed in this paper is available from the lead author 
Figure 1: Workflow of Systematic Literature Review

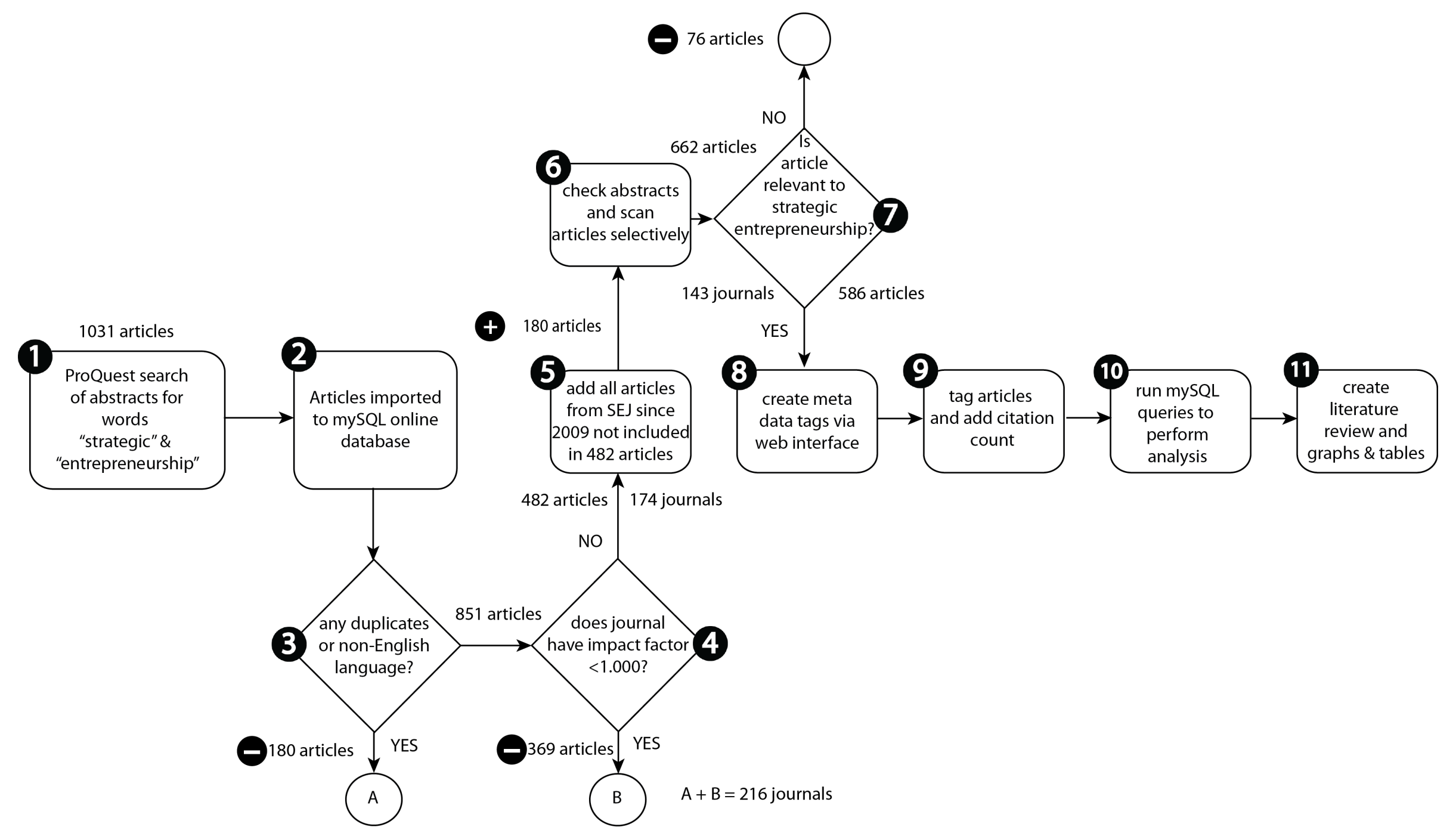


Table 1: Links between main themes and keywords

Figures in brackets show the number of articles tagged with this keyword

\begin{tabular}{|c|c|}
\hline Main Theme & Keywords \\
\hline $\begin{array}{l}\text { Sustainable Competitive } \\
\text { Advantage (sum: } 249 \text { ) }\end{array}$ & $\begin{array}{l}\text { firm performance (93), success (71), competitive advantage (33), survival (19), failure (18), innovation-based corporate } \\
\text { entrepreneurship (4), appropriation (4), service innovation (4), bankruptcy (2), entrepreneurial digital competencies (1) }\end{array}$ \\
\hline $\begin{array}{l}\text { Knowledge Management } \\
\text { (sum: } 333 \text { ) }\end{array}$ & $\begin{array}{l}\text { knowledge management (66), learning (58), knowledge spill over (40), technology transfer (39), research and development } \\
\text { (28), social capital (21), social network (19), IP (15), information technology (9), prediction (9), entrepreneurial knowledge } \\
\text { (8), management research (8), feedback (6), sensemaking (3), knowledge spill in (3), reciprocal knowledge flows (1) }\end{array}$ \\
\hline Ecosystems (sum: 374 ) & $\begin{array}{l}\text { network (77), ecosystem (53), government policy (50), culture (39), environmental dynamism (33), sustainability (28), cluster } \\
\text { (24), emerging economies (15), economic development (12), environmentalism (12), informal sector (7), emergent market (7), } \\
\text { developing country (6), bottom of the pyramid (5), crisis (5), inequality (1) }\end{array}$ \\
\hline Strategy (sum: 349) & $\begin{array}{l}\text { international entrepreneurship (67), decision making (45), transition (29), goal (24), marketing (23), strategic renewal (19), } \\
\text { market orientation (14), IPO (14), growth (11), life cycle (11), entrepreneurial strategy (11), competitors (10), spin-off (10), } \\
\text { diversification (9), new product performance (9), transnational entrepreneurs (6), born global (5), niche (5), portfolio } \\
\text { entrepreneurship (5), competitive intensity (4), resource scarce environment (4), mergers (3), context (3), buyouts (2), } \\
\text { competitor orientation (2), exit (1), cost benefit analysis (1), pivot (1), environmental antecedents (1) }\end{array}$ \\
\hline $\begin{array}{l}\text { Entrepreneurialism (sum: } \\
\text { 419) }\end{array}$ & $\begin{array}{l}\text { opportunity recognition (49), venture capital (44), opportunity exploitation (37), social entrepreneurship (32), innovation (29), } \\
\text { motivation (22), product innovation (20), gender (19), disruptive innovation (15), entrepreneurial behavior (13), entrepreneur } \\
\text { (11), employee entrepreneurship (10), creativity (10), opportunity creation (9), commercialisation (9), migrant (9), self- } \\
\text { efficacy (8), entrepreneurialism (7), personality (7), beliefs (6), entrepreneurial mindset (5), entrepreneurial intention (5), self- } \\
\text { employment (4), resilience (4), values (4), entrepreneurship process (4), entrepreneurship capability (3), youth (3), } \\
\text { opportunity seeking (3), serial entrepreneurship (3), resourcefulness (3), crowdfunding (3), passion (2), unproductive } \\
\text { entrepreneurship (2), imagination (2), entrepreneurship domain (1), optimism (1), entrepreneurial co-creation (1) }\end{array}$ \\
\hline $\begin{array}{l}\text { Organization \& } \\
\text { Management (sum: 459) }\end{array}$ & $\begin{array}{l}\text { governance (52), human capital (50), business model (37), alliance (32), structures (28), teams (26), organizational innovation } \\
\text { (22), stakeholder (21), leadership (17), collaboration (16), flexibility (14), top management team (13), board (13), institutional } \\
\text { entrepreneurship (13), trust (10), value chain (10), marketing innovation (9), career (8), NPO (8), upper echelons (7), process } \\
\text { innovation (7), NPD (6), embeddedness (5), organizational research (5), compensation (5), slack (4), equilibrium (4), } \\
\text { professional managers (3), CSR (3), institutional ambiguity (2), shared leadership (2), system dynamics (2), customer } \\
\text { orientation (1), input-output analysis (1), philanthropy (1), organizational capabilities (1), social competence (1) }\end{array}$ \\
\hline
\end{tabular}

